\title{
Safe Places and Unsafe Places: Geography and the 1996 Asylum and Immigration Act in the United Kingdom
}

\author{
Allen White
}

\begin{abstract}
Over the last decade and a half the international refugee régime, as enshrined by the 1951 Convention and 1967 Protocol has come under sustained attackin western states. This is because of implicit assumptions about the universalism of the refugee identity and the rootedness of national identities by the framers, drafters and subsequent commentators on international refugee law (see Malkki 1992, and Hyndman 1998). Critical approaches to international refugee law have suffered from underdeveloped ideas about space and about the relationship between geography and law. In this paper I point to geographical and geopolitical assumptions and thinking that lies behind the passage and enforcement of accelerated asylum determination and appeal procedures in the United Kingdom. I conclude by suggesting how the moral landscape of refugee and asylum law might be re-oriented to stress connections between the United Kingdom and persecuted and oppressed peoples rather than stress the protection of the UK's boundaries.

Précis
\end{abstract}

Dans les quinze dernières années, le régime international des réfugiés, préservé parle convention de 1951 et le Protocole de 1967, a fait l'objet d'attaques intensives dans les états occidentaux. Cela tient à un certain nombre de prises de parti implicites, duesaux législateurs initiaux et aux divers commentateurs ultérieurs des lois internationales sur les réfugiés; sur la question de l'universalitédel'identité de réfugié et de l'enracinement des

Allen White is a Ph.D. candidate in the Geography Division, Department of International Studies, Nottingham Trent University, Nottingham, $U K$, and Lecturer in Human Geography in St. David's University Lampeter, University of Wales, Ceredigion, Wales. identités nationales (voir Malkki 1992 et Hyndman 1998). Les approches critiques des lois internationales en matière de refuge ont souffert d'idées mal élaborées sur l'organisation del'espace, et sur la relation qui s'établit entre géographie et droit. Dans cet article j'attire l'attention sur les prises de parti et opinions de nature géographiqueet géopolitique qui sous-tendent la mise en placeet l'application des déterminations accélérées $d u$ droit d'asile et des procédures d'appel afférentes, au Royaume-Uni. Je conclus en suggérant de quelle façon le dispositif moral des lois sur les réfugiés et le droit d'asile deorait être réorienté pour mieux refléter les liensentre le Royaume-Uniet les peuples opprimés et persécutés, plutôt que de s'en tenir d̀ une emphase sur la protection des frontières du RoyaumeUni.

\section{Introduction}

The establishment and development of a international legal régime designed specifically to protect refugees cannot be totally isolated from a description, however brief, of the conditions and circumstances that lay behind its inception. In a certain light this history is a central part of the history of the 20th century, and is part of the horrors and carnage of what has been described as the "most terrible century in Western history" (Berlin, quoted in Hobsbawm 1994). Most commentators place the emergence of a recognizable "refugee problem" in the rise of nationalism at the end of the nineteenth century and especially in the first decades if the 20th century (see Marrus 1985, Loescher 1993, and Joly 1996). The consolidation of new and emerging nation-states required the re-writing of "community" and "belonging" around ideas of national unity on ethnic, religious and cultural grounds, these emerging nationalisms included and excluded spe- cific populations in particular territories. The political map of the world changed from a pre-modern "riot of diverse points of colour ... such that no clear pattern can be discerned in any detail" to a modern map of "little shading; neat flat surfaces ... there is very little, if any ambiguity or overlap" (Gellner, 1983 quoted in Malkki 1992). In the first half of the 20th century refugees emerged as a relatively new international problem, caught between nation states that rejected them and states that would not accept them (Marrus 1985; Loescher 1993). At the end of the both world wars millions of people were homeless, stateless and deprived of theirhuman rights, this had never been seen before (Marrus 1985; Loescher 1993): The international response to these stateless and rightless people was created and constructed in the context of these assumptions about citizenship, sovereignty and thenationstate.

The details of specific national myth building and the many different unfoldings of these nationalisms are not really the central or principal concerns to this paper, instead we should acknowledge that these processes form the backdrop to the establishment and development of the international legal refugee regime in the 20th century. Xenos (1993) writes for these reasons the refugee is the "modern political condition," a sentiment that echoes Arendt's more passionate description of modern refugees who

unlike their happier predecessors in the religious wars, were welcomed nowhere and could be assimilated nowhere. Once they had left their homeland they remained homeless, once they had left their state they became stateless; once they had been deprived of their human rights they were rightless, the scum of the earth. (Arendt 1967, 267) 
Underlying assumptions in international refugee law that claim the world can be easily divided into discreet units of sovereign states are not especially surprising given the common-sense practice of rooting particular peoples to particular places in Western political thought and culture and the ubiquity of territorialized concepts in everyday (and academic) language-"native soils," "homeland," "land" and "motherland" are cases in point (Malkki 1992). Naturalizing and botanical metaphors have been mobilized throughout history to conceive the relations between a "people" and a "place" producing a "sedentrisim" rooting people to places (ibid.). This is not an inert process; it actively pathologizes the displaced. Refugees, lacking a bodily connection to national territories, have been treated as having a lack of moral bearings (ibid.). This is most obvious in the postwarliterature on refugees howevermodern refugee studies and international refugee law still construct refugees as a "problem," marginalizing other and alternative refugee identities (ibid.).

We can argue then that the construction and framing of international refugee law depends on conceptions of a word divided into fixed units of sovereign states that peoples' identities are built within. International refugee law is stilted because it cannot take into accountmore open and fluid refugeeidentities because the refugee identity itself was patholgized in the immediate post war period. To be a refugee one must have suffered persecution, this persecution takes a highly specific form (based on ideological priorities of the West in the Cold War) there is no space in international refugee law to recognize less fixed and sedentary identities as legitimate refugees. Thus environmental refugees, female refugees or other groups of refugees are "written out" of the Geneva Convention. Through rooting refugee identities within these fixed ideas about the nation, identity and place international refugee law allows national asylum and immigration laws to "silence" these refugee identities. Legitimate refugee identities and narra- tives, at a stroke are deemed "bogus" or "non-Convention" refugees.

Another consequence of conceptualizing the world as divided into autonomous and sovereign states, is that international refugeelaw, and by extension international human rights law, is seen as means of delimiting state sovereignty (Malkki 1992; Hathaway 1991; and Goodwin-Gill 1983). The 1951 Convention guarantees refugees the right to seek asylum in signatory states but under international law it is an optional right of each state to grant or refuse asylum (Macdonald and Blake 1991; see also Lambert 1995). Thus, although it holds considerable symbolic power, the 1951 Convention does not explicitly challenge any signatory state's discretionary right to grant asylum (Macdonald and Blake 1991). The only obligation on states expressed in the Convention is contained in Article 33 which expressly forbids states from forcibly returning asylum-seekers to states, where they may face persecution, subject to certain conditions specified under the Convention. This principle of non-refoulement has evolved into a rule of customary law and has exposed tensions between aims and objectives of international and national legal systems such that:

On.the one hand, a State may choose to ensure compliance with its international obligations in various ways: there is no international requirement that the scope of these obligations be justicable in the State's own courts and tribunals. On the other hand a State is not entitled to rely on its domestic law to avoid its international responsibilities, and thus if decisions on those responsibilities are made by the executive government, it is the executive government which must ensure that the international law arguments are adequately dealt with.

(Crawford and Hyndman 1989, 157)

Thus international refugee and human rights law act as humanitarian benchmarks for domestic legislation, while in practice state law is used to govern a international human rights regime by states who see themselves as self-governing (Hathaway 1991). There is recognition that the universal human- ist rhetoric of the original Geneva Convention is flawed (see Greatbach, 1989; Crawley 1997; and Crawford and Hyndman 1989). Indeed the autonomous neutral and sovereign subject of humanism has been "widely accepted ... [as] a fiction" (Gregory 1994, 265, quoted in Hyndman 1998, 246). Many of these commentators seek to mobilize fresh interpretations of the Geneva Convention as part of a continuing project of using international refugee law as an exclusive site of struggle for promoting human rights around the world (and particularly in Western states) (Harvey 1997a). However this universalist humanitarianism that the Geneva Convention refugee definition and international refugee law is based upon acts to undermine the effective protection that international refugee law can promise refugees because it masks the unequal relations between states and groups of people-illegal immigrants, asylum seekers, economic migrants etc. (Hyndman 1998).

There are then at least two ways (pathologizing displacement and a universalist humanitarianism) in which implicit and explicit assumptions and discourses have informed and constructed an international legal refugee régime that effectively works against the role that international refugee law sees itself playing. The absence of any tradition of explicit criticism from within refugee law is noteworthyHarvey (1997a, 507) has commented that there is a sense that refugee law is "intrinsically critical." Tuitt (1996) has made a convincing case that refugee law actively functions to bar many of those whoneed protection and refugee status. Using refugee law she argues that the west has consistently prioritizing the reduction of the external costs of refugee movements (ibid.). Refugeelaw reduces the definition of a refugee toincludeonly very few applicants; refugee law shifts the burden to first asylum countries (who are often in no position to deal with large populations of refugees); refugee law emphasizes movement across international borders as a primary requirement of refugee identity containing the sick, the old, the young 
and marginalized within the persecuting state (ibid.). Inequality is built into and part of the refugee definition and the international legal régime.

Tuitt's approach is strongest when directed at the inequalities and biases of the international legal régime. However her arguments become less original as the analysis turns to the UK's domestic asylum and immigration legislation. $A$ more sophisticated conception of space in an analysis of refugee law might help reveal potentially emancipatory reflections on refugee law. A detailed analysis would reveal the geo-political assumptions and thinking that underpin the enactment and passage of asylum legislation in particular contexts. A detailed case study would also reveal the geographical and geopolitical thinking and biases that structure and inform practices in decision making and enforcement in particular places. Finally a case-study may help lead us to certain conclusions about how regulations and the law are formed and practiced and how they might be reformed in different ways to produce different conclusions and determinations of asylum cases.

With these points in mind I will see if looking at the UK's Asylum and Immigration legislation can help reveal how geographical and geo-political assumptions about social, political and economic realities have structured present legislation and practices. Firstly, however we need toexamine the connections between geography and law.

\section{Geography and Law- \\ Interpretative Communities}

There are progressive perspectives on law, informed by critical social theory and critical legal studies, that actively address the links between geography and law. The relationship between geography (meaning here in its broad sense-context) and law (acontextual) is inherently unstable, as Pue (1990) argues geography is by its very nature insurrectionary to the hegemonic view of law. The 1990s has seen a growing awareness about the relationship between geography and law (Urban Geog- rophy 1990 is devoted to theintersection between the two disciplines, see also Blomley and Clark 1990; Blomley 1994; Chouinard 1994; Delaney 1998; and Cooper 1998). This interest in establishing and pursuing connections does originate from within both disciplines, although geographers have taken more interest in law and legal issues than lawyers and legal exerts have in geography (Pue 1990). There is no one dominant consensus over the ways in which law and geography interact, indeed there are almost as many different approaches as there are researchers in the area, which is, if anything a sign of the novelty of this area of research. The recent theoretical approaches and analyses have in common an expansion of ideas about the relationship between the legal and the geographical beyond the narrowly defined model of "impact analysis" of a law onto a static spatial structure e.g. the housing structure. Instead, adopting critical legal perspectives has lead some to argue that law is "an open textured arena of discourse" which conditions the way in which we conceive of social life (Blomley 1992, 238). Side stepping positivist critiques of such an interpretative analysis of law Clarkargues that interpretation itself is a social act and a practice organized around shared social rules and codes of behaviour in particular spatial and social contexts (Clark 1989). Thus law is essentially an interpretative process that takes place in particular interpretative communities and contexts, for example government, the courts or the legislative.

So we can try and use these theoretical insights to reveal the unacknowledged discourses, assumptions and truth claims behind asylum law in the United Kingdom, and how these structure the ways in which asylum seeking is understood and viewed by policy makers. I am going to highlight two ways in which the system for asylum claims and appeals as laid out in the UK's Asylumand Immigration Act (1996) are based upon particular geographies and ideas about space. The parts of the acts I shall be looking at in detail are the accelerated procedures as set out by a) the Short Procedinowd b) Sectionone or White List apped cases

\section{The Short Procedure and Section One White List Cases}

As the name implies the Short Procedure shortens the length of time taken over asylum applications and is aimed at accelerating the initial determination of claims for asylum. Section One of the 1996 Asylum and Immigration Act is another example of accelerated procedures to move cases quickly through the asylum system, unlike the Short Procedure, Section One is aimed at accelerating post decision appeal procedures of challenge and review. The Short Procedure was a Home Office policy shift and required nolegislative changes. Section One aimed to accelerate the appeals procedure which had been outlined in the previous 1993 Asylum and Immigration Appeals Act (1993). This change then required primary legislation, Section One is part of the 1996 Asylum and Immigration Act. For a time, over 1995 and 1996, accelerated procedures were introduced for pre- and postdeterminations of asylum claims in the United Kingdom.

\section{The Short Procedure}

Prior to the introduction of the Short Procedure the standard (London based) procedure for dealing with asylum applications made from within the United Kingdom was to go to the Asylum Screening Unit(ASU) at Lunar House in Croydon. There the asylum seeker was given a Self Completed Questionnaire (SCQ) on his/her asylum claim-returnable within 28 days. The applicant was given advance warning of the asylum interview, and representations and evidencecould be presented to the Home Office up until the decision to accept or reject the asylum claim was made.

This arrangement changed under theShortProcedure. Under thenew procedures the asylum seeker is not given a SCQ, the interview is held on the same day as the initial claim to the ASU, further representations and evidencemust be presented to the Home Office over the next 5 working days and a decision is made within 3 weeks (Jagmohan 1996). 
Short Procedure interviews are shorter and less detailed than other interviews and suffer from a range of problems that typify asylum interviews; the chronology of the interview is backwards; translation and interpretations can be inaccurate; the asylum seeker is often exhausted after a long and tiring journey; the interview is the main source of information for the asylum claim a fact that the asylum seekermay notbe aware of (Refugee Legal Centre 1997a). Often the procedures are indeed "short," proper representation in interviews is importantbutimpossiblebecause interviews are often held on the sameday as the initial asylum claim, this can disorient asylum seekers (Jagmohan 1996). Under the Short Procedure asylumseekers are coerced into asylum interviews, which are usually the sole occasion for telling their story, without any allowance made for trauma, fatigue, distress, confusion and unfamiliarity with the asylum procedures (Refugee LegalCentre 1997a). When held at the port of entry the Short Procedure interviews are carried out by immigration officers who have no specialized training in asylum law and the political and social situation of other countries. In addition the place and site of the interview itself, in airports or ferry ports can be threatening environments.

The Home Office has argued that if asylum interviews take place immediately after the initial claim for asylum the asylum seeker's memory of events will be fresher (Jagmohan 1996). This rationale fundamentally misunderstands the nature of asylum claims. Asylum claims are rarely the result of particular persecution events, claims are more usually made after many events, often years of incremental acts of harassment, marginalization and persecution (ibid.). Home Office thinking is illustrated during the interview when asylum seekers are asked, "What particular event caused you to leave your country" after covering travel and family details (ibid.). A question like this, that prompts the respondent to highlight a single event or events, is an inappropriate means of drawing the full details about an asylum claim. In many cases follow up questions may not be asked, asylum seekers (without good representation) have no indication of the level of detail required to successfully claim asylum and may (reasonably) assume that details are notneeded as the interviewing officer hasn't asked for them (ibid.).

The HomeOffice, when moving people through the Short Procedure, implicitly acknowledges the need for advice for asylum seekers by giving them, before their interview, a leaflet entitled Information about Your Asylum Claim (Jagmohan 1996). However the information contained in the leaflet is far from satisfactory. There is nomention of the 1951 Convention definition, the criteria for being recognized a refugee, asylum seekers are told to give details of harassment and detention and not to give general country descriptions as their interviewing officer will be familiar with the situation in their home country - often not the case (ibid.). The leaflet fails to mention the right to an interpreter, to a copy of the interview notes and the procedure for submitting medical evidence, in sum the leaflet, published only in English, falls short of the advice available from a competent representative in a situation when circumstances can act to deny the presence of a representative (ibid.).

In May 1995 the Home Office introduced a pilot short procedure scheme to accelerate determinations of asylum claims from the nationals of eight countries, covering asylum claims whether they were made on entry or in country. Those countries were: Ghana, Nigeria, Uganda, India, Pakistan, Romania, Poland and Sri Lanka.

Reservations about the pilot scheme were voiced, on its introduction the Asylum Rights Campaign protested that the scheme would "impair the ability of a genuine refugee to properly represent his or her testimony" (ibid., 1).

All applications for asylum determined under the pilot Short Procedure were rejected, the scheme was declared a success by the Home Office and was expanded to include another 28 countries It covers asylum claims from all countries bar a selected few and those specific cases that, at the Home Office's discretion, could be considered substantively. The countries that are exempt are: Iraq, Afghanistan, Iran, Libya, Gulf States (bar Kuwait), Somalia, Liberia, Bosnia, Rwanda, Croatia, former Yugoslavia and Palestine(ibid.).

However exactly how the Home Office assessed the success of the pilot scheme remains a mystery to outsidersthere were no external assessments of the interviews held or of decisions made by the Home Office, there were also no consultations with asylum seekers put through the scheme. The Home Office pointed to the 100 percent refusal rate as evidence that the scheme properly pinpointed fraudulent claims and expanded the scheme before any appeals to these refusals were heard (ibid.). It is likely that the scheme would have been expanded regardless of the findings of any report.

\section{Section One White List Cases}

Section One of the 1996 Asylum and Immigration Act sought to establish the criteria whereby claims could be certified as bogus or without foundation after consideration by the Home Office. An asylum claim rejected and certified under Section One is put into an accelerated appeals procedure: asylum seekers were only given two days to lodge an appeal after a rejection; appeals could only be taken to the Special Adjudicator level with no further appeal allowed; adjournment rules were tightened; and the Special Adjudicators rulings had to be ready within 10 days(Harvey 1997a). Invariably questions were raised about the UK's commitment toefficientadministration at the expense of competent adjudication.

The drawing up of a "white list" of countries where the Secretary of State has determined that there is "in general no serious risk of persecution" raised some of the loudest objections. The countries named were Bulgaria, India, Cyprus, Pakistan, Ghana, Poland and Romania (Young 1997). The only credible interpretation of this "white list" of countries is that the nationality and origin of the asylum seeker automatically precludes the application from 
being genuine which raises questions about the commitment of the United Kingdom to individualized consideration of asylum claims (Refugee Legal Centre 1997a; and Harvey 1997b).

Section One certificates are also issued in cases that do not raise 1951 Convention grounds for persecution, where the Home Office considers the case to be "unfounded or frivolous" or where the asylum seeker has failed to either produce proper documentation or to have given a valid explanation for not producing proper documentation (Harvey 1997b). Clearly these are extremely wide grounds for restricting appeal rights but the rationale for certifying cases under Section One that has raised the most objection has been the "white list" of safe countries (Young 1997).

Used in conjunction the Short Procedure and Section One can mean that an asylum application from country $X$ (for example Romania) is put through an accelerated determination procedure, the claim is viewed as unfounded, certified under Section One of the 1996 act and put through accelerated appeal procedures, reducing an appeal's chance to overturn the refusal, so fewer cases are granted asylum (Jagmohan 1996).

\section{Legal Geographies}

A significant detail about the introduction of the Short Procedure and Section One of the 1996 Act is that both are dependent on particular assumptions about "persecution," politics and human rights in the world. Both are based on some kind of assessment of different parts of the world, dividing the world into "safe and unsafe" places, countries and regions, In other words the Short Procedureand Section One are based on specific political geographies organized and defined by the Home Office.

For the Short Procedure the production of these country lists was secret and not debated in public. The Home Office has so far refused to explicitly state why some countries were added and others taken off, except to state that the Short Procedure exists independently of the "White list" of safe countries. Clearly thoughgeo-politicalgoalsare playinga role-the inclusion of some countries (e.g., Algeria) and the omission of particular countries (e.g., Iraq) from the Short Procedure shows an awareness of political sensitivities rather than any firm commitments to protection from human rights abuses (Jagmohan 1996). This is not just about particular foreign policy imperatives-Sri Lanka was included on the original list for inclusion into Pilot Short Procedure scheme-it was withdrawn after a government assault on the Jaffna peninsula increased Western media attention on the civil war that has been ongoing for many years (ibid.)

Because the introduction of Section One and the use of a "white list" of countries presumed safe required the introduction of legislation the construction of this legislation was debated in the Houses of Parliament. These debates have been examined elsewhere toreveal how they centred on the criteria for assessing and categorizing particular countries as safe or unsafe, which in turn depended on the deployment of politically constructed ideas about the geography of human rights (Young 1997).

The debates about this part of the act centred on the criteria for determining if a country there is "in general no serious risk" in particular countries. They include: the stability of the country; state adherence to international human rights; the presence of democratic institutions and the media; the availability of legal avenues for protection. Thus a country is designated onto or of the "white list" once the "reality" of its socio-political characteristics were evaluated (ibid.). The evaluations of these different "realities" were based on a number of different assumptions. Firstly, the specific socio-political realities for particular countries was assumed to exist for all people at all times in each country, ignoring the specific situations and positions of minority populations. Secondly, regional disparities in persecution that may be related to ethnic or religious affiliations were also ignored. Thirdly, different and contradictory "realities" were mo- bilized in debates to argue for and against the inclusion of specific countries onto the white list.

In effect, then, the introduction of the Section One White List has seen the deployment and mobilization of specific geographical and geo-political knowledge's about different countries in an effort to evaluate and assess social political realities in each country (ibid.). Realities that are held to apply to all people in all parts of societies and across all parts of particular states (ibid.). In short then implicit and explicit geopolitical knowledges and geographical discourses about the nature and development of civil and political society in different societies and contexts across the world were mobilized over 1995-1996 to introduce a range of accelerated procedures.

\section{Conclusion}

To conclude, we can place the introduction of recent asylum legislation and the construction and organization of the asylum determination and appeals procedures in ideas about the "moral landscape" of refugee and asylum law in the United Kingdom. Recognizing persecution and offering safe haven from persecution constructs the world into "safe" places (states) and "unsafe" places (states) and the legal texts that do this are interconnected with other complex linguistic and cultural representations of the nation state, morality and power, producing a moral landscape of asylum (Kobayashi 1995). "We" are a morally good nation when we accept "the persecuted" and do not "persecute" others (ibid.). Refugee law and the establishment of asylum procedures are part of a whole series of linguistic representations and cultural activities that help define the moral authority and sovereignty of modern states (ibid.). Thus the United Kingdom, because it is a "moral," "good" and "democratic" state, offers "sanctuary" to victims of persecution from "immoral," "illegitimate" and "despotic" régimes. This moral landscape, most obviously associated with the certainties of the Cold War, in the post Cold War 1990 s is itself being invaded, by "illegal immigrants" 
and "hordes of bogus applicants" who wish to abuse the United Kingdom's "proud tradition" of offering asylum. You might notice that the debate, such as it is, is more likely to concentrate on asylum seekers as opposed to asylum itself.

When examined in a critical light and in any detail this moral landscape of refugee law in the United Kingdom crumbles. International refugee law has been constructed and designed to reflect Western interests and since its inception has sought to cater for Western Europe's geo-political interests (Tuitt 1996). The international legal régime's "international/humanitarian" ethos has been the means and the ends of this process, dismissing rival conceptions of the refugee while at the same time legitimizing Western interests through the universalism of the "international/ humanitarian" ethic (Tuitt 1995). The 1951 Convention definition has replaced all other pre-existing and competing definitions of the refugee-the Convention definition has fossilized a partial definition of the refugee (Tuitt 1996).

Through this asylum law in the United Kingdom has acted as a medium and context for the contraction of the refugee identity through a combination of the restriction of refugee rights and the exercising of state power in an asylum determination system that systematically "others" and humiliates asylum seekers and refugees (Paliwala 1995; for a Canadian example see Kobayashi 1995). This systematic and oppressiverewriting of refugee and asylum seeker's rights is not inevitable, however. The law has also acted, or has at least held the potential to act, in emancipatory ways, and can act in ways to perpetuate and also significantly to challenge " lived relations of oppression" (Chouinard 1994, 430). As an example an Immigration Appeals Tribunal hearing ruled on an appeal lodged by two Albanians from Kosovo that breaches of specific fundamental human rights amounted to persecution by the Serbian state, linking the 1951 Convention with International Human Rights legislation in a ruling that pro- vided a new analysis of the meaning of persecution in British law (Refugee Legal Centre 1997b). The adjudication of cases of asylum has represented an important space where, occasionally significant legal victories have provided a context where rights for asylum seekers can be defended and sometimes gained. A significant example of this is the recognition of genderbased persecution in Canadian Immigration Law after a number of successful appeals to asylum refusals were argued before the Immigration Appeals Board, a ruling thathas important implications for international law (Kobayashi 1995)

Asylum law acts is an important agent in the complex web of discourses that define and express the moral landscape of the nation, law is intimately involved with questions with what is good or bad for society, it is not always about punishing wrongdoing. There is no reason why laws as moral discourses cannotbe utilized to make connections between the United Kingdom and marginalized and persecuted people, rather than establish the boundaries and borders of a sovereign state. This might be based on ideas about geography and asylum, the inversion of theShort Procedure and the White List. Geo-political representations may be employed to target and highlight asylum claims from specific countries, or from particular parts of different countries as urgent and in need of attention. The moral locus of refugee law and its interpretation can be related to specific circumstances in particular places. In other words, refugee law can (potentially) be mobilized to make a connection between principles of social justice in areas of UK law (for example in rulings in Industrial Tribunals), with important developments in asylum jurisprudence in other countries and the social and political conditions in other parts of the world. This would require a re-writing of the social and political realities thathave been alluded to, a project in which geography could play an important role.

A re-writing of the moral landscape of asylum law in the United Kingdom would also dispel the myth that flows of asylum seekers and refugees are something that "just happens" to the United Kingdom (and other western states). In many cases western countries have played important parts in the creation of the social and political circumstances whereby people are persecuted and forced into fleeing their homes. For example the UK's arms trade to Sri Lanka, or the European Union's promotion of the ethnically divisive Vance-Owen peace plan in the Bosnian conflict (see also Black 1996).

Although I am describing a culture change in Home Office practice from a culture of disbelief to a culture of belief this could have beneficial effects on the present asylum system. Shortening the procedures to protect in specific cases would a) reduce appeals b) reduce costs as system would not be so overloaded during determinations and appeals and c) abusive cases could be given extra attention and dismissed. A recognition of the complex geographies of persecution and oppression across the globewould, at least, point out the problems of the universalist humanitarianism built into the present asylum determination system as well as acknowledge that different people and different groups are placed in unequal relation to each other.

\section{References}

Arendt, H. 1967. The Origins of Totalitarianism. London: Allen and Unwin.

Asylum and Immigration Act. 1996. London: Her Majesty's Stationery Office.

Asylum and Immigration Appeals Act. 1993. London: Her Majesty's Stationery Office.

Black, R. 1996. "Immigration and Social Justice: Towards a Progressive European Immigration Policy?" Transactions of the Institute of British Geographers 21, 64-75.

Blomley N., and G. Clark. 1990. "Law, Theory and Geography." Urban Geography 11, no. $5,433-46$.

Blomley, N. 1992. "The Business of Mobility." Canadian Geographer 6, 236-53.

Blomley, N. 1994. Law, Space and the Geographies of Power. London: Guilford Press.

Chouinard, V. 1994. "Geography Law and Legal Struggles: Which Ways Ahead?" Progress in Human Geography 18, no. 4, 41540. 
Clark, G. 1989. "Law and the Interpretative Turn in the Social Sciences." Urban Geography 10, no. 3, 209-28.

Cooper, D.1998. Governing Out of Order: Space, Law and the Politics of Belonging. London: Rivers Oram Press.

Crawford,J., and P. Hyndman. 1989. "Three Heresies in the Application of the Refugee Convention." International Journal ofRefugee Law 1, no. 2, 155-79.

Crawley, H. 1997. Women as Asylum Seekers: A Legal Handbook. London: ILP A and Refugee Action.

Delaney, D.1998. Race, Place and the Law 18361948. Austin, TX: University of Texas Press.

Gellner, E. 1983. Nations and Nationalism. New

York: Cornell University Press.

Goodwin-Gill, G. 1983. The Refugee in Interna tional Law. Oxford: Clarendon.

Greatbach, J. 1989. "The Gender Difference: Feminist Critiques of Refugee Discourse." International Journal of Refugee Law 1, no. 4, 518-27.

Gregory, D. 1994. "Humanistic Geography." In The Dictionary of Human Geography, 3d ed., edited by R. J. Johnston, D. Gregory, and D. Smith, 263-66. Oxford: Blackwells.

Harvey, C. 1997a. "False Images: The Law's Construction of the Refugee" Journal ofRefugee Studies 10, no. 4, 507-9.

-. 1997b. "Restructuring Asylum: Recent

Trends in the United Kingdom Asylum aw and Policy." International Journal of Refugee Law 9, no. 1, 60-73.

Hathaway, J. 1991. Reconceiving Refugee Law as Human Rights Protection." Journal of Refugee Studies 4, no. 2, 113-31.

Hobsbawm, E.1994. Age of Extremes. The

Short Twentieth Century 1914-1991.

London: Abacus.

Hyndman, J. 1998. "Managing Difference: Gender and Culture in Humanitarian Emergencies." Gender, Place and Culture 5, no. 3, 241-60.

Jagmohan, J. 1996. "The Short Procedure: An analysis of the Home Office scheme for rapid initial decisions in asylum cases." London: Asylum Rights Campaign.

Joly, D.1996. Haven or Hel/? Asylum Policies and

Refugees in Europe. London: Macmillan.

Kobayashi, A. 1995. "Challenging the National Dream: Gender Persecution and Canadian Immigration Law." In Nationalism, Racism and the Rule of Law, by P. Fitzpatrick, 6174. Dartmouth: Aldershot.

Lambert, H. 1995. Seeking Asylum. Comparative Law and Practice in Selected European Countries. London: Martinus Nijhoff.

Loescher, G.1993. Beyond Charity: International Co-Operation and the Global Refugee Crisis. Oxford: Oxford University Press.

Macdonald, I., and N. Blake. 1991 Macdonald's Immigration Law and Practice. London: Buttersworth and Sons.
Malkki, L 1992 "National Geographic: The Rooting of Peoples and the Territorialization of National Identity Among Scholars and Refugees." Cultural Anthropology 7 no. 1, 24-44.

Marrus,M.1985. The Unwanted. European Refugees in the Twentieth Century. New York: Oxford University Press.

Paliwala, A. 1995. "Law and the Constitution of the 'Immigrant' in Europe: A UK Policy Perspective." In Nationalism, Racism and the Rule of Law, by P Fitzpatrick, 77-96. Dartmouth: Aldershot.

Pue, W. 1990. "Wrestling with Law: (Geographical) Specificity vs. (Legal) Abstraction." Urban Geography 11, no. 6, 566-83.

Refugee Legal Centre. 1997a. Reviewing the Asylum Determination Procedure: A Casework Study. London: Refugee Legal Centre.

Refugee Legal Centre. 1997b. Annual Report 1996-1997. London: Refugee Legal Centre. Tuitt, P. 1995. "Racist Authorization, Inter pretative Law and the Changing Character of the Refugee." In Nationalism, Racism and the Rule of Law, by P. Fitzpatrick, 4560. Dartmouth: Aldershot

Tuitt, P. 1996 False Images: The Laws

Construc

tion of the Refugee. London: Pluto Press.

Xenos,N.1993. "Refugees: The Modern Politi cal Condition." Alternatives 18, 419-30.

Young, C. 1997. "Political Representation of Geography and Place in the United Kingdom Asylum and Immigration Bill (1995)." Urban Geography, Legal Geography Series 8, no. 1, 62-73. L

\section{Legitimate and Illegitimate Discrimination: New .Issues in Migration}

\section{Edited by Howard Adelman}

Toronto: York.Lancs Press, 1995; ISBN 1-55014-238-0;.287 pages, indexed; \$22.95

Freedom of movement: If the members of a state are forced to flee, the legitimacy of that government is questionable. On the other hand, if members cannot or must leave, again the government is not democratically legitimate. Immigration control: While limiting access and 'determining who mayor may not become members of a sovereign state remains a legitimate prerogative of the state, the criteria, .rulesand processes for doing so must be compatible with its character as a democratic state.

Legitimate and Ilkgitimate Discrimination: New Issues in Migration, edited by Professor Howard Adelman, deals with the qu.estiop of legitimacy with Cal)es sru.dies from the Developing World,. Europe, Australia, the United States, and Canada. CONTRIBUTORS

Rainer Baubock, Howard Adelman, Gaim Kibreab, A Essuman-Johnson, Grant M. Farr, Lawrence Lam, Oscar Schiappa Pietra, Tomas Hammar, Frederic Tiberghien (in French), Lois Foster, and Arthur C. Helton.

Available /tom:

Centre for Refugee Studies Fax: (416) 736-5837 ${ }^{\bullet}$ Email: refuge@yorku.ca 